\title{
PENGARUH CORPORATE SOCIAL RESPONSIBILITY (CSR), INTELLECTUAL CAPITAL, KEPEMILIKAN MANAJERIAL DAN FIRM SIZE TERHADAP KINERJA KEUANGAN
}

\author{
ANNI RIZQAYANTINI NOVITA \\ JONI SUSILOWIBOWO \\ Jurusan Manajemen, Fakultas Ekonomi, Universitas Negeri Surabaya, \\ Kampus Ketintang, Surabaya 60231 \\ Email: novita_anni@yahoo.com
}

\begin{abstract}
Absratct: This study aims to determine the effect of corporate social responsibility, intellectual capital, managerial ownership, and firm size on the financial performance of companies. Object of research is the consumer goods sub-sectors of manufacturing company listed on the Indonesian Stock Exchange in the year 2010 to 2013. Samples used in this study were 29 companies and the techniques used are saturated samples. The method used is quantitative. The data source used in this research is secondary data in the form of annual reports obtained from the Indonesia Stock Exchange (IDX). Results of this study indicate that CSR, managerial ownership and firm size has no effect on financial performance, while the effect of intellectual capital on financial performance.
\end{abstract}

Keywords: corporate social responsibility, intellectual capital, managerial ownership, firm size, financial performance.

\section{PENDAHULUAN}

Sebagian besar kegiatan
perusahaan akan memberikan
dampak bagi $\begin{array}{r}\text { lingkungan. } \\ \text { Permasalahan yang ditimbulkan }\end{array}$
terhadap lingkungan salah satunya
disebabkan oleh perkembangan
teknologi disegala bidang. Karena
dampak yang ditimbulkan dari suatu
operasional suatu perusahaan
terhadap masyarakat, maka
perusahaan harus mengontrol
dampak negatif tersebut sebaik
mungkin agar tidak merugikan
masyarakat sekitar.
Dalam daftar terbaru yang
dirilis oleh Blacksmith Institute, salah
satu wilayah di Indonesia pada tahun
2013 masuk sebagai pendatang baru
sebagai lokasi paling parah terpapar
polutan akibat limbah industri
maupun rumah tangga. Kawasan
sungai Citarum di Jawa Barat, sungai
yang menjadi sumber penghidupan
bagi sekitar 9 juta manusia yang
hidup disekitarnya dan sekitar 2.000
pabrik yang berdiri disepanjang aliran

sungai tersebut. Menurut hasil penelitian yang dilakukan oleh Blacksmith Institute dan Green Cross Switzerland ini, sungai Citarum yang digunakan sebagai sumber air untuk mengairi sawah dan wilayah pertanian lainnya, terkontaminasi limbah yang mengandung aluminium dan mangan. Dari hasil tes yang dilakukan di lokasi tersebut air yang biasa diminum oleh warga di sekitar sungai Citarum berada di level sangat berbahaya karena 1.000 kali di atas standar berbahaya yang ditetapkan di Amerika Serikat. (http://nationalgeographic.co.id).

Dari data tersebut merupakan salah satu fenomena mengapa corporate social responsibility (CSR) perlu diterapkan pada perusahaan. Sesuai dengan Undang-undang no. 40 pasal 74 Tahun 2007 tentang Perseroan Terbatas (UU PT) bahwa perseroan yang menjalankan kegiatan usahanya di bidang dan/atau berkaitan dengan sumber daya alam wajib melaksanakan 
Tanggung Jawab Sosial dan Lingkungan (TJSL).

Seiring dengan

perkembangan teknologi, persaingan di dunia bisnis semakin ketat. Hal ini menyebabkan perusahaan harus memiliki keunggulan atau karakter agar dapat bersaing dengan dunia bisnis global. Menurut Salim dan Karyawati (2013) intellectual capital merupakan semua pengetahuan karyawan yang dimiliki suatu perusahaan untuk menciptakan nilai tambah dan keunggulan suatu perusahaan. Menurut Sawarjuno (2003) dalam Dewi (2011) seiring dengan perubahan ekonomi yang berkarakteristik ekonomi berbasis ilmu pengetahuan dengan penerapan manajemen pengetahuan (knowledge management) maka kemakmuran suatu perusahaan akan tergantung pada suatu penciptaan transformasi dan kapitalisasi dari pengetahuan itu sendiri. Agar dapat bersaing di dunia bisnis global maka perusahaan mengubah bisnis yang berdasarkan pada tenaga kerja menjadi bisnis yang berdasarkan ilmu pengetahuan, sehingga pertumbuhan suatu perusahaan tergantung pada ilmu pengetahuan para karyawannya.

Menurut Ardianingsih (2010) tujuan utama perusahaan untuk meningkatkan nilai perusahaan dan kemakmuran para pemegang saham. Adanya konflik yang terjadi antara manajer dengan pemegang saham diantaranya adalah dalam pembuatan keputusan yang berkaitan dengan aktivitas pencarian dana (financing decision) dan bagaimana dana yang diperoleh tersebut diinvestasikan. Dengan adanya struktur kepemilikan manajerial, perusahaan memberikan kesempatam bagi manajer untuk memiliki saham perusahaan sehingga manajer dapat bekerja secara optimal (Wardani dan Hermuningsih, 2011). Sehingga dengan adanya kepemilikan manajerial, pihak manajerial suatu

$\begin{array}{lcr}\text { perusahaan } & \text { akan } & \text { bekerja } \\ \text { semaksimal } & \text { mungkin } & \text { dalam } \\ \text { meningkatkan } & \text { kinerja } & \text { keuangan } \\ \text { perusahaan } & \text { tersebut } & \text { untuk } \\ \text { meningkatkan } & \text { kemakmuran para } \\ \text { pemegang saham yang di antaranya } \\ \text { adalah dirinya sendiri. }\end{array}$

Kinerja keuangan juga dipengaruhi oleh ukuran perusahan (firm size). Menurut Widjaja (2009) dalam Kurnia dan Mawardi (2012) firm size adalah ukuran yang menunjukkan besar kecilnya suatu perusahaan, antara lain total penjualan, rata-rata tingkat penjualan, dan total aktiva. Pada umumnya perusahaan besar memiliki total aktiva yang besar mampu menghasilkan laba yang besar. Hal ini juga dibutuhkan oleh para shareholder dalam pengambilan keputusan. Semakin besar ukuran perusahan maka kesempatan untuk memperoleh laba juga semakin besar.

Annual report merupakan salah satu media yang dapat digunakan dalam pengungkapan informasi keuangan perusahaan. Sesuai dengan PSAK No.1 tahun 2009 perusahaan dapat pula menyajikan laporan tambahan seperti laporan mengenai lingkungan hidup dan nilai tambah (value added statement), khususnya bagi industri dimana faktor-faktor lingkungan hidup memegang peranan penting dan bagi industri yang menganggap pegawai sebagai kelompok pengguna laporan keuangan. Penilaian terhadap kinerja suatu perusahaan ini dapat dilakukan dengan melakukan analisis terhadap laporan keuangannya. Laporan keuangan tersebut akan memberi informasi kepada pihak diluar perusahaan.

Tujuan penelitian ini untuk mengetahui dan menganalisis pengaruh corporate social responsibility (CSR), intellectual capital, kepemilikan manajerial dan firm size terhadap kinerja keuangan 
pada perusahaan manufaktur yang terdaftar di Bursa Efek Indonesia.

\section{KAJIAN PUSTAKA}

\section{Corporate Social Responsibility (CSR)}

CSR didasarkan pada dampak sosial atas kegiatan operasional yang dilakukan oleh suatu perusahaan. Informasi yang diungkapkan dalam annual report tidak hanya informasi keuangan perusahaan, tetapi juga diharapkan mengungkapkan informasi mengenai dampak sosial dan lingkungan hidup yang diakibatkan oleh perusahaan tersebut.

Kemajuan suatu perusahaan juga meperhatikan lingkungan sekitarnya. CSR juga dapat dilakukan perusahaan untuk menciptakan image yang baik dikalangan shareholder dan stakeholder. Sehingga segala kegiatan yang dilakukan oleh suatu perusahaan akan memperoleh kepercayaan dari berbagai pihak. Menurut Hendrik (2007:1) CSR adalah komitmen perusahaan dalam dunia bisnis untuk berkontribusi dalam pengembangan ekonomi yang berkelanjutan dengan memperhatikan tanggung jawab sosial perusahaan. Pengungkapan CSR dalam laporan tahunan memperkuat image perusahaan dan menjadi sebagai salah satu pertimbangan yang diperhatikan investor maupun calon investor dalam menanamkan modalnya karena menganggap bahwa perusahaan tidak hanya mengejar profit tetapi sudah memperhatikan lingkungan dan masyarakat.

Menurut Global Compact Initiative (2006) menyebutkan pemahaman CSR dengan 3P yaitu profit, people, planet. Pengungkapan CSR menjelaskan bahwa perusahaan tidak hanya mencari keuntungan melainkan juga memberikan kesejahteraan kepada orang lain dan menjamin keberlangsungan hidup lingkungan sekitar. Pengungkapan tanggung jawab sosial perusahaan bertujuan untuk memperlihatkan aktivitas sosial yang dilakukan oleh perusahaan dan pengaruhnya terhadap masyarakat. Penilaian pengungkapan CSR dalam penelitian menggunakan corporate social responsibility index dengan 79 item yang telah ditentukan oleh GRI. Hal yang dicakup dalam GRI adalah lingkungan, ekonomi, HAM, tenaga kerja, produk, dan masyarakat. Angka index digunakan untuk mengetahui sebarapa luas pengungkapan CSR oleh perusahaan dalam annual report. Perhitungan angka index menurut Mulia dan Mutmainah (2009) adalah sebagai berikut :

$$
\text { CSRI }=\frac{\text { Jml Item Informasi CSR yg Diungkapkan }}{\text { Jml Item Informasi yg Diwajibkan (79item) }}
$$

\section{Stakeholder Theory}

Menurut Hadi (2010:93) tanggung jawab sosial perusahaan yang semula hanya diukur sebatas indikator ekonomi (economic focused) dalam laporan keuangan, kini harus memperhitungkan faktorfaktor sosial (social dimentions) terhadap stakeholder, baik internal maupun eksternal. Stakeholder merupakan semua pihak baik internal dan eksternal yang memiliki hubungan baik yang bersifat mempengaruhi maupun dipengaruhi oleh suatu perusahaan. Deegan (2004) dalam Ulum (2007) menyatakan bahwa teori stakeholder menekankan akuntabilitas organisasi jauh melebihi kinerja keuangan atau ekonomi sederhana.

Teori ini menyatakan bahwa organisasi secara sukarela mengungkapkan informasi tentang kinerja lingkungan, sosial dan intelektual mereka, melebihi dan di atas permintaan wajibnya, untuk memenuhi ekspektasi sesungguhnya atau yang diakui oleh stakeholder. 
Dengan adanya informasi sosial yang di ungkapkan pada annual repot diharapkan dapat menarik para investor.

\section{Signaling Theory}

Menurut Wirakususma dan Yuniasih (2007) dalam Kurnianto (2011) konsep signaling theory menyatakan bahwa perusahaan memberikan sinyal-sinyal kepada pihak luar perusahaan dengan tujuan meningkatkan nilai perusahaan. Pengungkapan CSR diharapkan memberikan sinyal positif kepada para stakeholder sehingga dapat mencipkan image baik bagi perusahaan.

\section{Intellectual Capital}

Intellectual capital atau modal intelektual memiliki peran yang penting di dalam suatu perusahaan. Intellectual capital merupakan sumber daya berupa pengetahuan yang dimiliki karyawan pada perusahaan yang akhirnya mendatangkan keuntungan bagi perusahaan tersebut yang didukung oleh proses informasi untuk menjalin hubungan dengan pihak dari luar perusahaan. Menurut Salim dan Karyawati (2013) intellectual capital mencakup semua pengetahuan karyawan organisasi dan kemampuan perusahaan untuk menciptakan nilai tambah dan keunggulan kompetitif.

Sawarjuwono (2003) dalam dewi (2011) menyatakan bahwa intelellectual capital merupakan jumlah dari apa yang dihasilkan oleh tiga elemen utama organisasi (human capital, structural capital, dan customer capital) yang berkaitan dengan pengetahuan dan teknologi yang dapat memberikan nilai lebih bagi perusahaan berupa keunggulan bersaing organisasi. Intellectual capital dapat dibagi menjadi komponen modal fisik, modal manusia, dan modal struktural (Salim dan Karyawati, 2013)

Modal fisik (physical capital) menunjukkan hubungan harmonis yang dengan mitranya, baik dari pemasok, pelanggan, pemerintah dan masyarakat sekitar, modal fisik dalam model Pulic disebut dengan capital employed (CE). Modal manusia (human capital) menunjukkan kemampuan perusahaan dalam mengelola sumber daya manusia, intelectual capital jenis ini menganggap manusia sebagai aset yang bernilai karena pengetahuan yang dimiliki. Modal struktural (structural capital) merupakan modal yang dimiliki perusahan meliputi pengetahuan yang akan tetap berada dalam perusahaan. Structural Capital menunjukkan pengetahuan yang akan tetap ada dalam perusahaan yang bersifat bukan manusia, seperti: rutinitas perusahaan, prosedur, sistem, budaya, dan database.

Menurut Pulic (1998) dalam Ulum (2007) langkah-langkah yang dilakukan dalam menghitung nilai VAIC $^{\mathrm{TM}}$ adalah :

Pertama menghitung value added (VA), dengan rumus :

$$
\text { VA = OUTPUT - INPUT }
$$

Keterangan :

Output: Penjualan+pendapatan lain

Input: Beban dan biaya (selain biaya karyawan)

Kedua menghitung capital emoyed (CE), human capital (HU), dan structural capital (SC), dapat diukur dengan dengan rumus sebagai berikut :

$$
\begin{gathered}
\mathrm{CE}=\text { EKUITAS + LABA BERSIH } \\
\mathrm{HU}=\text { BEBAN KARYAWAN } \\
\text { SC = VA - HU }
\end{gathered}
$$

Ketiga menghitung value added capital employed (VACA), value added human capital (VAHU), dan structural capital value added (STVA), ketiga komponen tersebut dapat dihitung dengan rumus :

$$
\begin{aligned}
& \mathrm{VACA}=\mathrm{VA} / \mathrm{CE} \\
& \mathrm{VAHU}=\mathrm{VA} / \mathrm{HU}
\end{aligned}
$$


STVA $=$ SC / VA

Keempat menghitung $\mathrm{VAIC}^{\mathrm{TM}}$. VAIC $^{\mathrm{TM}}$ mengindikasi kemampuan intelektual organisasi yang dapat juga dianggap sebagai BPI (Business Performance Indicator), rumus :

$$
\mathrm{VAIC}^{\mathrm{TM}}=\mathrm{VACA}+\mathrm{VAHU}+\text { STVA }
$$

\section{Kepemilikan Manajerial}

Menurut Ardianingsih dan Ardiyani (2010) semakin besar proporsi kepemilikan manajemen pada suatu perusahaan, maka manajemen cenderung berusaha lebih giat untuk kepentingan pemegang saham yang tidak lain adalah dirinya sendiri. Menurut Jensen dan Meckling (1976) dalam Ardianingsih dan Ardiyani (2010) teori keagenan adalah teori yang menjelaskan agency relationship dan masalah-masalah yang ditimbulkannya. Agency relationship merupakan hubungan antara dua pihak, dimana pihak pertama bertindak sebagai principal/pemberi amanat dan pihak kedua disebut agent yang bertindak sebagai perantara yang mewakili principal dalam melakukan transaksi dengan pihak ketiga. Pihak principal memberi kewenangan kepada agent untuk melakukan transaksi atas nama principal dan diharapkan dapat membuat keputusan yang terbaik bagi prinsipalnya. Kepemilikan manajerial dilakukan untuk memberi kesempatan kepada para manajer dalam kepemilikan saham sehingga dapat meningkatkan kinerja manajer, tidak hanya untuk kepentingan perusahaan melainkan untuk kepentingan para pemegang saham yang salah satunya adalah dirinya. Kepemilikan manajerial dapat dihitung dengan menggunakan rumus sebagai berikut:

$$
\text { K. Manajerial }=\frac{\text { Saham yg Dimiliki Pihak Manajerial }}{\text { Total Saham Beredar }} \times 100 \%
$$

\section{Firm Size}

Firm size menggambarkan besar kecilnya suatu perusahaan. Perusahaan dengan ukuran besar akan mendapatkan kesempatan yang besar dalam memperoleh sumber pendanaan dari berbagai sumber. Sedangkan perusahaan dengan ukuran kecil lebih fleksibel dalam menghadapai ketidakpastian. Widjadja (2009) dalam Kurnia dan Mawardi (2012) firm size adalah suatu ukuran yang menunjukkan besar kecilnya suatu perusahaan, antara lain total penjualan, rata-rata tingkat penjualan, dan total aktiva. Pada umumnya perusahaan besar yang memiliki total aktiva yang besar mampu menghasilkan laba yang besar. Firm size dalam penelitian ini di ukur dengan persamaan berikut: firm size $=$ Ln total asset

\section{Kinerja Keuangan}

Menurut Fahmi (2011:239) kinerja keuangan adalah suatu analisis yang dilakukan untuk melihat sejauh mana perusahaan telah melaksanakan kewajiban dengan menggunakan aturan-aturan keuangan secara baik dan benar. Kinerja keuangan merupakan gambaran tentang kondisi keuangan suatu perusahaan selama periode tertentu. Informasi kinerja keuangan bermanfaat untuk memprediksi kapasitas perusahaan dalam menghasilkan laba dari sumber daya yang ada.

Pengukuran kinerja keuangan sangat penting bagi suatu perusahaan, karena pengukuran kinerja keuangan bermanfaat untuk memberikan informasi mengenai kondisi suatu perusahaan dalam periode tertentu kepada pihak yang berkepentingan dalam mengambil keputusan. Salah satu rasio kinerja keuangan adalah profitabilitas, artinya kemampuan perusahaan untuk memperoleh keuntungan atau laba agar dapat terjaga 
kontinuitasnya. Dalam penelitian ini, profitabilitas menggunakan ROA.

ROA merupakan rasio profitabilitas yang paling sering diperhatikan, karena mampu menunjukkan keberhasilan suatu perusahaan dalam menghasilkan laba selain itu adanya gap dari penelitian terdahulu. Rasio profitabilitas diproksikan dengan ROA, rumus:

$$
R O A=\frac{\text { Laba Bersih }}{\text { Total Aktiva }} \times 100 \%
$$

\section{Corporate Social Responsibility (CSR) dan Kinerja Keuangan}

Perusahaan

yang

mengungkapkan CSR diharapkan dapat menciptakan image yang baik dikalangan stakeholder dan shareholder-nya, sehingga dapat meningkatkan laba perusahaan yang nantinya akan meningkatkan kinerja keuangan. Menurut Putri dan Rustiyaningsih (2013) perusahaan yang memiliki kepedulian sosial akan mendapatkan simpati dari masyarakat, dan sebagai akibatnya perusahaan tersebut memiliki kinerja penjualan yang baik karena masyarakat memberikan apresiasi dengan mengkonsumsi produk perusahaan tersebut. Hasil berbeda ditunjukkan oleh Marisa et al., (2013) bahwa CSR tidak berpengaruh terhdap kinerja keuangan. Karena dengan adanya CSR perusahaan harus mengeluarkan biaya tambahan sehingga akan mengurangi laba. Penelitian lain ditunjukkan oleh Kurnianto dan Prastiwi (2011) yang menejlaskan bahwa CSR tidak berpengaruh terhadap kinerja keuangan.

\section{Intellectual Capital dan Kinerja Keuangan}

Intellectual Capital merupakan modal berupa pengetahuan yang dimiliki oleh karyawan suatu perusahaan yang akan membuat perusahaan tersebut memiliki karakter yang nantinya akan meningkatkan kinerja perusahaan itu sendiri. Menurut Ningrum dan Rahardjo (2012) variabel intellectual capital yang diukur dengan VAIC ${ }^{\text {TM }}$ diperoleh berpengaruh diperoleh berpengaruh signifikan positif terhadap profitabilitas ROA. VAIC ${ }^{\text {TM }}$ yang besar menunjukkan bahwa perusahaan lebih banyak mengalokasikan dana yang besar untuk modal intelektual dalam meningkatkan sumber daya manusia, struktural, dan sumber daya fisik lainnya yang nantinya akan berpengaruh di masa depan terhadap peningkatan laba. Hasil berbeda ditunjukkan oleh Panjaitan dan Sadalia (2012) bahwa Intellectual capital tidak berpengaruh terhadap kinerja keuangan perusahaan. Hal ini karena intellectual capital yang telah dikeluarkan oleh perusahaan belum secara langsung mempengaruhi upaya perusahaan mendapatkan ROA yang lebih baik.

\section{Kepemilikan Manajerial dan Kinerja Keuangan}

\begin{tabular}{lrr}
\multicolumn{2}{c}{ Besarnya } & proporsi \\
kepemilikan manajerial & suatu \\
perusahaan maka pihak manajerial & merusahaan akan berusaha \\
mengoptimalkan kinerja untuk
\end{tabular} kepentingan para pemegang saham yang tidak lain adalah dirinya sendiri. Menurut Ardiyaningsih dan Ardiyani (2010) kepemilikan manajerial berpengaruh terhadap kinerja perusahaan. Namun, tingkat kepemilikan manajerial yang terlalu tinggi juga dapat berdampak buruk terhadap perusahaan. Kepemilikan manajerial yang tinggi, manajer mempunyai hak voting yang tinggi sehingga manajer mempunyai posisi yang kuat untuk mengendalikan perusahaan, hal ini dapat menimbulkan masalah pertahanan, dalam artian, adanya kesulitan bagi para pemegang saham eksternal 
untuk mengendalikan tindakan manajer. Hasil berbeda ditunjukkan oleh Wiranata dan Nugrahanti (2013) yang menyatakan bahwa kepemilikan manajerial tidak memiliki pengaruh yang signifikan terhadap kinerja keuangan dengan alasan yang sama dengan peneliti sebelumnya bahwa kepemilikan manajerial yang terlalu rendah membuat manajer belum dapat berpartisipasi aktif dalam membuat suatu keputusan.

\section{Firm Size dan Kinerja Keuangan}

Perusahaan yang memiliki ukuran perusahaan yang besar makan perusahaan akan mendapatkan kesempatan besar dalam memperoleh sumber pendanaan, sehingga nantinya akan meningkatkan laba. Menurut Kurnia dan Mawardi (2012) firm size memiliki pengaruh positif terhadap (ROA). Semakin banyak asset, maka semakin besar pula peluang bank untuk menghasilkan laba. Semakin besar ukuran bank maka semakin bagus kinerja perusahaan tersebut. Ukuran perusahaan dapat mempengaruhi kemampuan suatu perusahaan dalam menghasilkan laba. Penelitian lain dilakukan oleh Fachrudin (2013) yang menjelaskan bahwa ukuran perusahaan tidak berpengaruh terhadap kinerja keuangan suatu perusahaan karena ukuran perusahaan bukan jaminan suatu perusahaan memiliki kinerja yang baik.

Berdasarkan teori dan penelitian terdahulu, maka hipotesis dalam penelitian ini adalah :

$\mathrm{H}_{1}$ : Diduga corporate social responsibility (CSR), intellectual capital, struktur kepemilikan, dan firm size secara simultan berpengaruh terhadap return on assets (ROA).

$\mathrm{H}_{2}$ : Diduga corporate social responsibility (CSR) berpengaruh terhadap return on assets (ROA).
$\mathrm{H}_{3}$ : Diduga intellectual capital berpengaruh terhadap return on assets (ROA).

$\mathrm{H}_{4}$ : Diduga struktur kepemilikan berpengaruh terhadap return on assets (ROA).

$\mathrm{H}_{5}$ : Diduga firm size berpengaruh terhadap return on assets (ROA).

\section{METODE}

Penelitian ini merupakan jenis penelitian kuantitatif kausal, dimana penelitian kausal bertujuan mendapatkan bukti hubungan sebab akibat. Data yang digunakan dalam penelitian ini adalah data sekunder. Sumber data dalam penelitian ini bersumber dari Bursa Efek Indonesia berupa annual report perusahaan untuk periode $2010-2013$.

Populasi dalam penelitian ini adalah seluruh perusahaan manufaktur sub-sektor barang konsumsi yang terdaftar di Bursa Efek Indonesia. Teknik pengambilan sampel dalam penelitian ini adalah dengan metode saturation sampling atau biasa yang dikenal dengan sampel jenuh. Sampling dapat dikatakan jenuh jika seluruh populasi dijadikan sampel. Hal ini dilakukan karena jumlah populasi relatif kecil, kurang dari 30 sampel.

Variabel dalam penelitian ini dibedakan menjadi dua yaitu, variabel dependen dan variabel independen. Variabel dependen dalam penelitian ini yaitu kinerja keuangan (Y). Sedangkan variabel independen dalam penelitian ini yaitu, corporate social responsibility (CSR) $\left(\mathrm{X}_{1}\right)$, intellectual capital $\left(\mathrm{X}_{2}\right)$, kepemilikan manjerial $\left(X_{3}\right)$ dan firm size $\left(\mathrm{X}_{4}\right)$.

Teknik pengumpulan data yang digunakan adalah melalui data sekunder berwujud data dokumentasi atau data laporan yang tersedia yaitu annual report perusahaan manufaktur yang terdaftar di Bursa Efek Indonesia periode 2010-2013. Teknik analisis data dalam penelitian ini 
menggunakan analisis regresi linear berganda. Model regresi yang digunakan akan menunjukkan hubungan yang signifikan dan representative atau disebut BLUE (Best Linear Unbiased Modeli).

Model regresi yang baik diharuskan memenuhi beberapa asumsi yang disebut sebagai asumsi klasik. Uji asumsi klasik yang digunakan yaitu uji normalitas, uji multikolinearitas, uji heteroskedastisitas, dan uji autokorelasi (Ghozali, 2012). Teknik analisis dalam penelitian ini menggunakan bantuan IBM SPSS 20.

\section{HASIL}

Deskripsi variabel penelitian ini dimaksudkan untuk melihat karakteristik variabel-variabel yang diteliti. Dalam penelitian ini ada empat variabel bebas yang merupakan faktor-faktor yang mempengaruhi kinerja keuangan pada perusahaan manufaktur yang terdaftar di Bursa Efek Indonesia.

Statistik deskriptif untuk variabel ROA dapat diketahui nilai rata-rata (mean) ROA dari perusahaan manufaktur sub sektor barang konsumsi yang terdaftar di Bursa Efek Indonesia pada tahun 2010-2013 adalah sebesar 14,7728. Nilai ROA terendah yaitu sebesar $-11,63$ pada tahun 2012, sedangkan nilai ROA tertinggi yaitu sebesar 65,72 yang pada tahun 2013. Variabel CSR memiliki nilai rata-rata (mean) 0,1685. Nilai CSR terendah yaitu sebesar 0,06 pada tahun 2010, sedangkan nilai CSR tertinggi yaitu sebesar 0,33 pada tahun 2013. Variabel intellectual capital (VAIC ${ }^{\mathrm{TM}}$ ) memiliki nilai rata-rata (mean) 4,6192. Nilai intellectual capital (VAIC ${ }^{\mathrm{TM}}$ ) terendah yaitu sebesar 5,04 pada tahun 2012, sedangkan nilai intellectual capital (VAIC ${ }^{\mathrm{TM}}$ ) tertinggi yaitu sebesar 10,88 pada tahun 2010. Variabel kepemilikan manajerial memiliki nilai rata-rata (mean) 7,0436. Nilai kepemilikan manajerial terendah yaitu sebesar 0,00 pada tahun 2010, sedangkan nilai kepemilikan manajerial tertinggi yaitu sebesar 71,26 pada tahun 2013. Variabel firm size memiliki nilai rata-rata (mean) 28,1113. Nilai firm size terendah yaitu sebesar 25,18 pada tahun 2010, sedangkan nilai firm size tertinggi yaitu sebesar 31,99 pada tahun 2012.

Uji normalitas dalam penelitian ini menggunakan grafik histogram dan grafik P-Plot, grafik histogram menunjukkan pola distribusi normal, yaitu memiliki bentuk seperti lonceng pada grafik histogram dan pada grafik P-P plot, dapat dilihat titik-titik menyebar mengikuti pola garis diagonal. Kedua grafik ini menunjukkan bahwa model regresi berdistribusi normal, sedangkan untuk statistik normalitas menggunakan uji kolmogorovsmirnov menunjukkan tingkat signifikansi sebesar 0,966 yang nilainya lebih besar dari 0,05 sehingga dapat disimpulkan bahwa data berdistribusi normal. Hasil uji multikolinearitas menunjukkan nilai VIF adalah lebih kecil dari 10 yang merupakan batas maksimal nilai toleransi, artinya pada model regresi tidak terjadi multikolinearitas. Hasil uji heteroskedastisitas dengan grafik scatterplot dapat terlihat titik-titik menyebar secara acak, tidak membentuk sebuah pola serta tersebar baik diatas maupun dibawah angka 0 pada sumbu Y. Hal ini dapat disimpulkan bahwa tidak terjadi heteroskedastisitas pada model regresi ini, sehingga layak digunakan pada penelitian ini sedangkan untuk statistik heteroskedastisitas menggunakan uji glejser yang menunjukkan nilai signifikansi masing-masing variabel sebesar $0.166, \quad 0.143, \quad 0.070$, dan 0.357 menunjukkan nilai lebih besar dari nilai signifikansi 0.05 sehingga dapat disimpulkan bahwa dalam model 


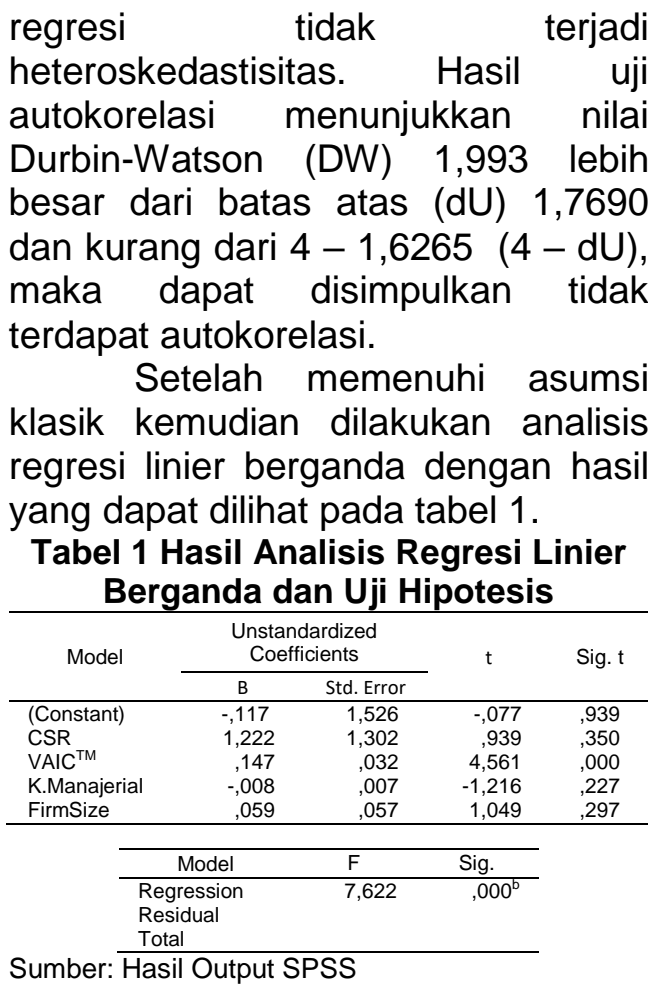

Pada tabel 1 diketahui bahwa nilai signifikansi $F$ sebesar 0.000 , nilai tersebut lebih kecil dari 0.05 yang berarti bahwa $\mathrm{H}_{0}$ ditolak dan $\mathrm{H}_{a}$ diterima. Sehingga dapat disimpulkan bahwa seluruh variabel independen secara simultan berpengaruh terhadap kinerja keuangan. Variabel CSR menunjukkan nilai signifikan $t$ sebesar $0.350>0.05$ sehingga disimpulkan bahwa CSR tidak berpengaruh terhadap kinerja keuangan. Variabel VAIC $^{T M}$ menunjukkan nilai signifikan $t$ sebesar $\quad 0.000<0.05 \quad$ sehingga disimpulkan bahwa VAIC ${ }^{\text {TM }}$ berpengaruh terhadap kinerja perusahaan. Variabel kepemilikan manajerial menunjukkan nilai signifikan $t$ sebesar $0.227>0.05$ sehingga disimpulkan bahwa kepemilikan manajerial tidak berpengaruh terhadap kinerja perusahaan. Variabel firm size menunjukkan nilai signifikan $t$ sebesar $\quad 0.297<0.05 \quad$ sehingga disimpulkan bahwa firm size tidak berpengaruh terhadap kinerja perusahaan.

\section{PEMBAHASAN}

\section{Pengaruh Corporate Social Responsibility, Intllectual Capital, Struktur Kepemilikan, dan Firm Size secara simultan terhadap Return On Assets (ROA).}

Pada penelitian ini
menunjukkan perhitungan secara simultan CSR, intellectual capital (VAIC ${ }^{\mathrm{TM}}$ ), kepemilikan manajerial dan firm size berpengaruh signifikan terhadap variabel dependen ROA. Hal ini dapat dikatakan bahwa kinerja perusaahaan akan meningkat ketika sebuah perusahaan memperhatikan CSR, intellectual capital, struktur kepemilikan dan firm size. Keempat variabel tersebut secara simultan berpengaruh terhadap kinerja keuangan yang diproksikan dengan ROA, hal ini dapat terlihat pada hasil uji $F$ yang menunjukkan nilai signifikansi sebesar $0.000<0.05$.

\section{Pengaruh Corporate Social Responsibility (CSR) terhadap Return On Assets (ROA)}

Hasil penelitian ini menunjukkan CSR yang diproksikan menggunakan CSR index tidak berpengaruh terhadap ROA. Hasil penelitian ini sejalan dengan penelitian Marisa (2013) yang menjelaskan bahwa CSR tidak memberikan pengaruh signifikan terhadap kinerja keuangan dimana laporan tahunan hanya mengungkapkan hal positif tentang suatu perusahaan sehingga dengan adanya pertimbangan investor tersebut akan memicu keuangan perusahaan menjadi menurun dimana laba juga akan menurun. Penelitian lain yang dilakukan oleh Kurnianto (2011) juga menyatakan bahwa tidak terdapat pengaruh yang signifikan antara CSR dan kinerja keuangan perusahaan. $\mathrm{Hal}$ ini menunjukkan bahwa semakin tinggi tingkat pengungkapan CSR justru 
investor akan memberikan respon yang negatif. Dalam hal ini perusahaan dengan pengungkapan CSR yang tinggi justru semakin tidak diminati investor untuk berinvestasi. Variabel CSR secara parsial tidak berpengaruh terhadap kinerja keuangan yang diproksikan dengan ROA, hal ini dapat terlihat pada hasil uji $t$ yang menunjukkan nilai signifikansi sebesar $0.350>0.05$.

\section{Pengaruh Intellectual Capital terhadap Return On Assets (ROA)}

Hasil penelitian ini menunjukkan intellectual capital yang diproksikan menggunakan VAIC $^{\text {TM }}$ berpengaruh terhadap ROA. Hasil penelitian ini sejalan dengan penelitian yang dilakukan oleh Ningrum dan Raharjo (2012) VAIC $^{\text {TM }}$ memiliki pengaruh yang signifikan terhadap kinerja keuangan yang diproksikan dengan ROA, hal ini menunjukkan bahwa semakin besar modal intelektual yang dialokasikan oleh perusahaan secara signifikan akan semakin meningkatkan profitabilitas ROA. Penelitian lain yang dilakukan oleh Salim dan karyawati (2013) yang menyatakan bahwa modal intelektual berpengaruh terhadap kinerja keuangan perusahaan, dengan meningkatkan pengetahuan dan pengembangan struktural capital yang dimilikinya akan mencapai keunggulan bersaing yang akan menghasilkan kinerja keuangan yang lebih tinggi. Variabel intellectual capital secara parsial berpengaruh terhadap kinerja keuangan yang diproksikan dengan ROA, hal ini dapat terlihat pada hasil $u j i$ yang menunjukkan nilai signifikansi sebesar $0.000<0.05$.

\section{Pengaruh Struktur Kepemilikan terhadap Return On Assets (ROA)}

Hasil penelitian ini menunjukkan kepemilikan manajerial tidak berpengaruh terhadap ROA. Hasil penelitian ini sejalan dengan penelitian yang dilakukan oleh Wiranata dan Nugrahanti (2013) yang menyatakan bahwa kepemilikan manejerial tidak berpengaruh terhadap kinerja perusahaan dikarenakan kepemilikan manajerial terlalu rendah sehingga kinerja manajer dalam mengelola perusahaan kurang optimal dan manajer sebagai pemegang saham minoritas belum dapat berpartisipasi aktif dalam membuat suatu keputusan diperusahaan. Penelitian lain yang dilakukan oleh Widyawati (2013) yang menyatakan bahwa kepemilikan manajerial tidak memiliki pengaruh yang signifikan terhadap kinerja keuangan dengan alasan yang sama dengan peneliti sebelumnya bahwa kepemilikan manajerial yang terlalau rendah sehingga manajer belum merasakan manfaat dari kepemilikannya tersebut. Variabel kepemilikan manajerial secara parsial tidak berpengaruh terhadap kinerja keuangan yang diproksikan dengan ROA, hal ini dapat terlihat pada hasil uji $t$ yang menunjukkan nilai signifikansi sebesar 0.227>0.05.

\section{Pengaruh Firm Size terhadap Return On Assets (ROA)}

Hasil penelitian ini
menunjukkan firm size tidak berpengaruh terhadap ROA. Hasil penelitian ini sejalan dengan penelitian yang dilakukan oleh Fachrudin (2013) yang menjelakan bahwa ukuran perusahaan tidak berpengaruh signifikan terhadap kinerja keuangan suatu perusahaan karena ukuran perusahaan bukan jaminan perusahaan akan memiliki kinerja yang baik. Penelitian lain dilakukan oleh Sari dan Budiasih (2014) yang menyatakan bahwa firm size tidak berpengaruh terhdap kinerja keuangan. Hal ini disebabkan apabila semakin besar firm size maka perusahaan akan membutuhkan banyak biaya untuk menjalankan 
operasionalnya. Variabel firm size secara parsial tidak berpengaruh terhadap kinerja keuangan yang diproksikan dengan ROA, hal ini dapat terlihat pada hasil uji $t$ yang menunjukkan nilai signifikansi sebesar 0.297>0.05.

\section{KESIMPULAN}

Corporate social responsibility, intellectual capital, kepemilikan manajerial dan firm size secara simultan berpengaruh terhadap kinerja keuangan yang diproksikan dengan ROA pada perusahaan manufaktur sub sektor barang konsumsi yang tedaftar di BEI pada tahun 2010-2013.

CSR secara parsial tidak berpengaruh terhadap kinerja keuangan yang diproksikan dengan ROA pada perusahaan manufaktur sub sektor barang konsumsi yang tedaftar di BEl pada tahun 20102013. Hal ini disebabkan investor beranggapan bahwa perusahaan hanya mengungkapkan hal-hal yang positif saja dalam laporan tahunan sehingga pengungkapan tersebut tidak akan mempengaruhi keputusan para investor.

Intellectual capital (VAIC ${ }^{\mathrm{TM}}$ ) secara parsial berpengaruh terhadap kinerja keuangan yang diproksikan dengan ROA pada perusahaan manufaktur sub sektor barang konsumsi yang tedaftar di BEI pada tahun 2010-2013. Hal ini dikarenakan intellectual capital merupakan sumber daya berupa pengetahuan yang dimiliki oleh karyawan dalam suatu perusahaan sehingga dapat meningkatkan kinerja perusaahaan.

Kepemilikan manajerial secara parsial tidak berpengaruh terhadap kinerja keuangan yang diproksikan dengan ROA pada perusahaan manufaktur sub sektor barang konsumsi yang tedaftar di BEI pada tahun 2010-2013. Hal ini karena minimnya kepemilikan saham yang dimiliki oleh majerial suatu perusahaan, sehingga manajer tidak dapat berperan penuh dalam pengambilan keputusan.

Firm size secara parsial tidak berpengaruh terhadap kinerja keuangan yang diproksikan dengan ROA pada perusahaan manufaktur sub sektor barang konsumsi yang tedaftar di BEl pada tahun 20102013. Hal ini karena semakin besar ukuran perusahaan, maka semakin besar biaya yang dikeluarkan untuk kegiatan operasinalnya sehingga akan mengurangi laba.

Berdasarkan kesimpulan yang telah disajikan, maka saran yang dapat diberikan penulis adalah sebagai berikut; sebaiknya perusahaan lebih memperhatikan pengungkapan CSR dalam annual report, tidak hanya mengungkapkan hal-hal positif saja, perusahaan sebaiknya memperhatikan target profitabilitas yang akan dicapai, karena akan menunjukkan kemampuan perusahaaan dalam menghasilkan laba sehingga akan mempengaruhi keputusan para investor, dan bagi peneliti selanjutnya, diharapkan dapat menambah proksi dalam menghitung kinerja keuangan suatu perusahaan dan memperluas populasi penelitian yang digunakan.

\section{DAFTAR PUSTAKA}

Ardianingsih, Arum dan Ardiyani, K. 2010. Analisis Pengaruh Struktur Kepemilikan Terhadap Kinerja Perusahaan. Jurnal Pena, Vol. 19, No. 2. Hal. 97109.

Dewi, Citra P. 2011. Pengaruh Intellectual Capital terhadap Kinerja Keuangan Pada Perusahaan Manufaktur Yang Terdaftar Di BEI Tahun 20072009. Skripsi diterbitkan. Semarang: UNDIP 
Fachrudin, K.A. 2013. Analisis Pengaruh Struktur Modal, Ukuran Perusahaan, dan Agency Cost Terhadap Kinerja Perusahaan. Jurnal Akuntansi dan Keuangan, Vol. 13 No. 1. Hal. 37-46

Fahmi, Irham. 2011. Analisis Laporan Keuangan. Lampulo: Alfabeta.

Ghozali, Imam. 2012. Aplikasi Analisis Multivariate Dengan Progra, Semarang: Badan Penerbit Universitas Diponegoro.

Global Reporting Initiative. 2006. Pedoman Laporan Berkelanjutan versi 3.0

Hadi, Nor. 2010. Corporate Social Responsibility, Yogyakarta: Graha IImu.

Hendrik, Budi Untung. 2007. Corporate Social Responsibility. Jakarta: Sinar Grafika.

Http://nationalgeographic.co.id. 2013. Kurnia, I dan Mawardi, W. 2012. Analisis Pengaruh Bopo, Ear, Lar Dan Firm Size Terhadap Kinerja Keuangan (Studi kasus pada bank umum konvensional yang terdaftar di Bursa Efek Indonesia periode 2008-2011). Diponegoro Journal Of Management, Vol. 1, No. 2. Hal. 49-57.

Kurnianto, E.A dan Prastiwi A. 2011 Pengaruh Corporate Social Responsibility Terhadap Kinerja Keuangan Perusahaan (Studi Empiris pada Perusahaan Perbankan yang Terdaftar di Bursa Efek Indonesia Tahun 2005 - 2008). Skripsi diterbitkan. Semarang: UNDIP.
Marisa et al. 2013. Pengaruh Corporate Social Responsibility Terhadap Kinerja Keuangan Pada Perusahaan Manufaktur Yang Terdaftar Di Bei Tahun 2007-2009. Jurnal IImiah Mahasiswa Universitas Surabaya, Volume 2, Nomor 1. Hal. 1-19.

Mulia, R dan Mutmainah, S. 2009. Pengaruh karakteristik Corporate Governance Terhadap Luas Pengungkapan Corporate Social Responsibility. Jurnal Wahana Akuntansi, Vol 4, No. 1. Hal. 75-94.

Ningrum, N.R dan Raharjo H.N. 2012. Analisis Pengaruh Intellectual Capital Dan Corporate Governance Terhadap Financial Performance. Diponegoro Journal Of Accounting, Vol 1, No. 2. Hal. 1-15.

Panjaitan, I.D. dan Sadalia, I. 2012. Pengaruh Intellectual Capital Terhadap Kinerja Keuangan Pada Bank Pembangunan Daerah Di Indonesia. Artikel jurnal.

Putri, Mardiansari dan Rustiyaningsih, S. 2013. Tanggung Jawab Sosial dan Kinerja Keuangan pada Perusahaan Manufaktur Go Publik Di Bursa Efek Indonesia. Jurnal Riset Manajemen dan Akuntansi, Volume 1, No. 1. Hal. 70-80.

Salim, S.M dan Karyawati, G. 2013. Pengaruh Modal Intelektual Terhadap Kinerja Keuangan. Journal of Business and Entrepreneurship, Vol. 1, No. 2. Hal. 1-12.

Sari, Ni Made V. dan Budiasih I.G.A.N. 2014. Pengaruh Debt to Equity Ratio, Firm Size, 
Inventory Turn Over dan Assets

Turn Over Pada

Profitabilitas.Jurnal Akuntansi,

Vol 6, No.2. ISSN: 2302-8556.

Ulum, Ihyaul. 2007. Pengaruh Intellectual Capital Terhadap Kinerja Keuangan Perusahaan Perbankan Di Indonesia. Tesis diterbitkan. Semarang: UNDIP.

Wardani, D.K dan Hermuningsih, S. 2011. Pengaruh Struktur Kepemilikan Terhadap Nilai Perusahaan Dengan Kinerja Keuangan Dan Kebijakan Hutang Sebagai Variabel Intervening. Jurnal Nasional, Vol. 15, No.1. Hal. 27-36.

Widyawati, Maria. F. 2013. Pengaruh Dewan Direksi, Komisaris Independen, Komite Audit, Kepemilikan Manajerial dan Kepemilikan Institusional Terhadap kinerja keuangan. Jurnal Ilmu Manajemen. Vol. 1, No.1. Hal. 234-249

Wiranata, Y. A dan Nugrahanti Y.W. 2013. Pengaruh Struktur Kepemilikan Terhadap Profitabilitas Perusahaan Manufaktur di Indonesia. Jurnal Akuntansi dan Keuangan. Vol. 15, No. 1. Hal.15-26. 